Int. J. Dev. Biol. 58: 873-879 (2014)

doi: $10.1387 / \mathrm{ijdb} .140193 \mathrm{aw}$

\title{
In silico identification of the genes for sperm-egg interaction in the internal fertilization of the newt Cynops pyrrhogaster
}

\author{
AKIHIKO WATANABE ${ }^{1 * *}$ and ERIKO TAKAYAMA-WATANABE ${ }^{2}$ \\ ${ }^{1}$ Department of Biology, Faculty of Science and \\ ${ }^{2}$ Institute of Arts and Sciences, Yamagata University, Kojirakawa, Yamagata, Japan
}

\begin{abstract}
A specific sperm-egg interaction in the oviductal matrix is crucial for internal fertilization of the red-bellied newt, Cynops pyrrhogaster. An understanding of the molecular basis of this interaction is expected to elucidate the evolutionary history of internal fertilization in amphibians. Recently, deep sequencing technology has provided global gene information even in nonmodel animals, allowing us to understand specific features of the molecular mechanisms underlying fertilization in $C$. pyrrhogaster. In the present study, we screened de novo assembled RNAseq from ovary, testis, and oviduct samples in $C$. pyrrhogaster and identified the base sequences encoding zona pellucida (ZP) proteins, voltage-dependent $\mathrm{Ca}^{2+}$ channels, and cysteine-rich secretory proteins (CRISPs), which respectively are sperm receptors for egg envelopes, major mediators of sperm intracellular signaling, and expected extracellular modulators for sperm function in the female reproductive tract. In the ovary, ZP homologues of all six subgroups were found, including a ZP1 homologue that was newly found in amphibians, a ZP4 homologue, and six ZPC homologues. The unique combination of ZP proteins suggests a new mechanism for sperm binding to egg envelopes in the internal fertilization of $C$. pyrrhogaster. In the testis, CaV1.1, 1.2, and 3.2, which are $\mathrm{L}$ - and T-type voltage-dependent $\mathrm{Ca}^{2+}$ channels, were found as potential mediators for the internal fertilization-specific sperm-egg interaction. We also found CRISP 2 in the oviduct, which is speculated to participate in the sperm-egg interaction. These results indicate that the de novo assembled RNAseq is a powerful tool allowing analysis of the specific sperm-egg interactions in C. pyrrhogaster.
\end{abstract}

KEY WORDS: ZP proteins, $C a^{2+}$ channel, CRISP, RNAseq, internal fertilization, urodele

\section{Introduction}

Animals reproduce in various environments in water and on land. Some environmental conditions involve unstable factors that influence the success of fertilization and cause the optimization of the sperm-egg interaction (Inoda and Morisawa, 1987; Takai and Morisawa, 1995). Rapid evolution of the genes that are significant for fertilization may involve the modification of the sperm-egg interaction that contributes to the diversification of reproductive modes during adaptation to fertilization environments.

CatSper is a sperm-specific cation channel in mammals (Ren et al., 2001). Its primary role is $\mathrm{Ca}^{2+}$ influx into spermatozoa to induce hyperactivated motility, which ensures that spermatozoa are propelled through the oviductal matrix and penetrate the egg coat known as the zona pellucida for fertilization (Yanagimachi, 1994). In primates, the CatSpergene has been positively selected with an accompanying modification of the putative channel function (Podlaha and Zhang, 2003), whereas it has been lost in the genomes of the model animals belonging to Aves, Anura, Teleosts, and Agnatha (Cai and Clapham, 2008). Other molecules, such as the $\mathrm{Na}^{+}-\mathrm{Ca}^{2+}$ exchanger and voltage-dependent $\mathrm{Ca}^{2+}$ channels (VDCCs), appear to be substituted for CatSper to increase the intracellular $\mathrm{Ca}^{2+}$ for the initiation or activation of sperm motility in those animals (Morisawa et al., 1999; Vines et al., 2002; Froman and Feltmann, 2005). Zona pellucida (ZP) proteins are also known to be rapidly evolving molecules (Goudet et al., 2008). They are divided into six subgroups, ZP1, ZPA/ZP2, ZPB/ZP4, ZPC/ ZP3, ZPAX, and ZPD, and contain a ZP domain that most likely

Abbreviations used in this paper: CRISP, cysteine rich secretory protein; VDCG, voltagedependent $\mathrm{Ca}^{2+}$ channel; ZP, zona pallucida.

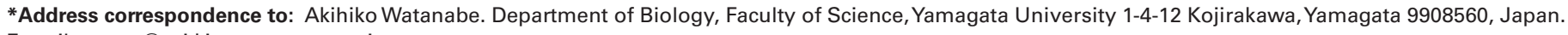
E-mail: watan@sci.kj.yamagata-u.ac.jp
}

Supplementary Material (two figures and two tables) for this paper is available at: http://dx.doi.org/10.1387/ijdb.140193aw 

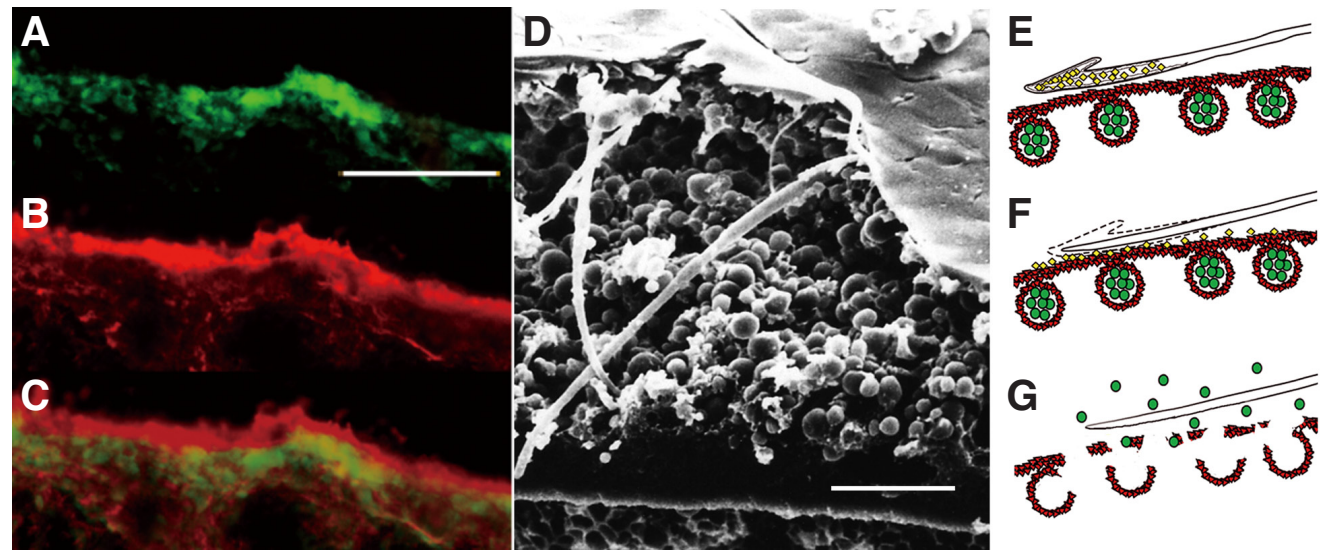

Fig. 1. Acrosome reaction-associated initiation of sperm motility based on the fine structure of the surface of jelly layer in C. pyrrhogaster. (A-C) Immunohistochemical localizations of sperm motilityinitiating substance (SMIS) (A), acrosome reaction-inducting substance (ARIS) (B), and both merged (C). ARIS and SMIS are localized in the outer surface of egg jelly and just beneath the ARIS-localizing area, respectively. Bar: $75 \mu \mathrm{m}$. (D) Scanning microscopic image of the surface of jelly layer showing sheet structure in the outer surface and granules beneath it. Bar: $10 \mu \mathrm{m}$. (E-G) A possible mechanism for acrosome reaction-associated initiation of sperm motility. Quiescently stored spermatozoa are inseminated on to the surface of jelly layer (E) and undergo acrosome reaction in response to the ARIS (red). Acrosomal enzymes were exposed to lyse the ARIS-localizing sheet structure covering the surface of the jelly layer (F), which results in exposure of the SMIS to affect spermatozoa for the motility initiation (G). Photographs and illustrations are reproduced with permission from Int. J. Dev. Biol. (2010) 54: 591-597.

mediates the polymerization of those molecules into filamentous components of the vitelline envelope (Killick et al., 1995). A few genes for ZP proteins are disrupted, depending on the species, which results in the expression of different combinations of ZP proteins. The rapid evolution of ZP proteins might influence their function in sperm binding to the vitelline envelope (Hedrick, 2008) which is mediated by ZPA/ZP2 in mouse and human (Bleil and Wassarman, 1988; Avella et al., 2014) and by ZPC/ZP3 in addition to ZPA/ZP2 in X. laevis (Tian et al., 1999; Vo and Hedrick, 2000; Hedrick, 2008).

The reproductive mode of amphibians is highly diversified to finally evolve internal fertilization (Duellman and Trueb, 1994). In the newt Cynops pyrrhogaster, a specific state of sperm motility to penetrate the jelly layer is induced in association with an acrosome reaction on the basis of fine structures on the jelly surface (Watanabe et al., 2010; Takayama-Watanabe et al., 2015) (Fig. 1). This mechanism is crucial for the internal fertilization of $C$. pyrrhogaster (Takahashi et al., 2006) and contributes to the initiation of sperm motility inside the female body. The motility is pharmacologically suggested to be mediated by a unique molecular mechanism in which L-type and T-type VDCCs act in distinct sites of the sperm midpiece (Takahashi et al., 2013). In addition, C. pyrrhogaster spermatozoa bind to the vitelline envelope in passing through the jelly layer, though Cynops ZPC, unlike $X$. laevis ZPC, is suggested not to act as a sperm receptor. Elucidation of the substantial changes in the genes involved in the achievement of the internal fertilization of $C$. pyrrhogaster will be significant to understand the mechanism underlying the diversification of reproductive modes in amphibians and to understand the evolutional history leading to internal fertilization in tetrapods. However, these substancial changes are largely unknown because of poor gene information. Recently, global gene information expressing in a specific organ was constructed in newts (Looso et al., 2013; Yokoe et al., 2014; Nakamura et al., 2014). In the present study, we focused on genes for ZP proteins, VDCCs, and cysteine-rich secretory proteins (CRISP) that were prospectively critical for sperm-egg interaction in the internal fertilization of $C$. pyrrhogaster, and features of their expression were examined using the RNAseq data constructed via de novo assembly of cDNA from testis, ovary, and oviduct samples.

\section{Results and Discussion}

In the de novo assembled data on RNAseq from ovary and testis samples, 12 and 15 base sequences were annotated as ZP proteins and $\alpha 1$ subunits of VDCC, respectively. The base sequences for ZP proteins possessed putative coding regions encoding 328-789 amino acids, including two encoding partial amino acid sequences of the ZP domain (Table 1). The ZP proteins of Xenopus (Silurana) tropicalis registered in NCBI GenBank are the proteins of 375-690 amino acids, suggesting that most base sequences for $Z P$ proteins in the RNAseq data were nearly full size.

In contrast, some base sequences for the $\alpha 1$ subunits of VDCCs were too small to encode full amino acid sequences (Table 2). In this case, one to five base sequences were identified for each subunit (Table S2). This feature in the $\alpha 1$ subunits of VDCCs may be caused by the presence of multiple isoforms expressed in distinct cell types of the testes as well as by assembly error due to the lack of reference sequences. In the case of protamine genes that had been identified in spermatids (Yoshinobu et al., 1997), full base sequences obtained by expression screening of a cDNA library were found in the RNAseq data from the testis samples (comp59911 for protamine 1 and comp43001 for protamine 2) with 98\% identity (Fig. S1). Although comp59911 had an additional 1012 base sequence in the 5'-region that resulted in nonsense coding, the 3'-region potentially encoded the full amino acid sequence of protamine 1. Thus, comp59911 is supposed to be the protamine $1 \mathrm{cDNA}$ sequence fused with that of an unknown gene due to assembly error. The high homologies of comp59911 and comp43001 to the protamine 1 and 2 genes, respectively, indicate that reliable genetic information can be obtained at least in protein coding regions from the de novo assembled RNAseq data.

\section{Zona pallucida (ZP) proteins}

Base sequences homologous to all six subgroups of ZP proteins were found in the RNAseq data from ovary (Table 1). They included a base sequence annotated as a ZP4 homologue (Table 1). This is the first finding of $Z P 4$ expression in amphibians. They also included every base sequence for ZPB or the other subgroups of ZP proteins except for ZPC/ZP3: six distinct base sequences 
TABLE 1

\section{CONTIG SEQUENCES HOMOLOGOUS TO ZP PROTEINS IN THE RNASEQ DATA FROM OVARY}

\begin{tabular}{|c|c|c|c|c|c|c|c|}
\hline contig & length (bp) & zp domain (bp) & accession & species & E-value & bit score & identical (\%) \\
\hline \multicolumn{8}{|l|}{$\mathrm{ZP} 1$} \\
\hline comp38331 & 1942 & $672-1455$ & $\begin{array}{l}\text { ELK13491.1 } \\
\text { EHH22824.1 } \\
\text { ELV10238.1 }\end{array}$ & $\begin{array}{l}\text { Pteropus alecto } \\
\text { Macaca mulatta } \\
\text { Tupaia chinensis }\end{array}$ & $\begin{array}{l}2.63 \mathrm{E}-116 \\
6.68 \mathrm{E}-115 \\
4.84 \mathrm{E}-114\end{array}$ & $\begin{array}{l}371.7 \\
369.0 \\
366.7\end{array}$ & $\begin{array}{l}40.7 \\
39.7 \\
39.0\end{array}$ \\
\hline \multicolumn{8}{|l|}{ ZPA/ZP2 } \\
\hline comp46414 & 2316 & $792-1572$ & $\begin{array}{c}\text { NP_001081858.1 } \\
\text { AAD12172.1 } \\
\text { AAK84067.1|AF401322_1 }\end{array}$ & $\begin{array}{c}\text { Xenopus laevis } \\
\text { Xenopus laevis } \\
\text { Discoglossus pictus }\end{array}$ & $\begin{array}{l}6.37 \mathrm{E}-142 \\
1.22 \mathrm{E}-140 \\
4.06 \mathrm{E}-137\end{array}$ & $\begin{array}{l}445.3 \\
442.2 \\
432.9\end{array}$ & $\begin{array}{l}41.7 \\
41.5 \\
39.4\end{array}$ \\
\hline \multicolumn{8}{|l|}{ ZPB/ZP4 } \\
\hline $\begin{array}{l}\text { comp67568 } \\
\text { (partial) }\end{array}$ & 1068 & $573-1383$ & $\begin{array}{c}\text { EMP28460.1 } \\
\text { NP_001081068.1 } \\
\text { NP_988854.1 } \\
\text { EMP33668.1 } \\
\text { EMP28460.1 } \\
\text { NP_990210.1 }\end{array}$ & $\begin{array}{c}\text { Chelonia mydas } \\
\text { Xenopus laevis } \\
\text { Xenopus (Silurana) tropicalis } \\
\text { Chelonia mydas } \\
\text { Chelonia mydas } \\
\text { Gallus gallus }\end{array}$ & $\begin{array}{l}1.02 \mathrm{E}-143 \\
2.99 \mathrm{E}-142 \\
4.97 \mathrm{E}-137 \\
3.88 \mathrm{E}-91 \\
4.28 \mathrm{E}-88 \\
6.73 \mathrm{E}-86\end{array}$ & $\begin{array}{l}440.7 \\
437.6 \\
424.1 \\
289.7 \\
285.8 \\
280.4\end{array}$ & $\begin{array}{l}51.2 \\
47.2 \\
45.2 \\
56.0 \\
58.8 \\
56.3\end{array}$ \\
\hline \multicolumn{8}{|l|}{ ZPC/ZP3 } \\
\hline comp68248 & 1528 & 213-987 & $\begin{array}{l}\text { AAV35105.1 } \\
\text { AAB39079.1 } \\
\text { AAV35193.1 }\end{array}$ & $\begin{array}{c}\text { Meleagris gallopavo } \\
\text { Xenopus laevis } \\
\text { Gallus gallus }\end{array}$ & $\begin{array}{l}6.03 E-115 \\
1.40 E-114 \\
2.90 E-114\end{array}$ & $\begin{array}{l}358.2 \\
357.5 \\
356.3\end{array}$ & $\begin{array}{l}45.1 \\
47.1 \\
52.3\end{array}$ \\
\hline comp64853 & 1565 & $318-1095$ & $\begin{array}{l}\text { AAV35105.1 } \\
\text { AAV35107.1 } \\
\text { AAV35103.1 }\end{array}$ & $\begin{array}{c}\text { Meleagris gallopavo } \\
\text { Lyrurus tetrix } \\
\text { Centrocercus urophasianus }\end{array}$ & $\begin{array}{l}2.66 \mathrm{E}-118 \\
4.28 \mathrm{E}-117 \\
1.03 \mathrm{E}-116\end{array}$ & $\begin{array}{l}367.1 \\
364.0 \\
363.2\end{array}$ & $\begin{array}{l}64.1 \\
62.4 \\
62.3\end{array}$ \\
\hline comp62734 & 1342 & $93-831$ & $\begin{array}{c}\text { EMP27581.1 } \\
\text { AAI58454.1 } \\
\text { ADH93592.1 }\end{array}$ & $\begin{array}{l}\text { Chelonia mydas } \\
\text { Xenopus (Silurana) tropicalis } \\
\text { Acipenser sinensis }\end{array}$ & $\begin{array}{l}1.07 \mathrm{E}-103 \\
3.89 \mathrm{E}-94 \\
5.51 \mathrm{E}-62\end{array}$ & $\begin{array}{l}331.6 \\
300.8 \\
216.9\end{array}$ & $\begin{array}{l}50.2 \\
40.0 \\
36.4\end{array}$ \\
\hline $\begin{array}{l}\text { comp60094 } \\
\text { (partial) }\end{array}$ & 2438 & $15-705$ & $\begin{array}{l}\text { AAV35105.1 } \\
\text { AAH72326.1 } \\
\text { AAV35103.1 }\end{array}$ & $\begin{array}{c}\text { Meleagris gallopavo } \\
\text { Xenopus laevis } \\
\text { Centrocercus urophasianus }\end{array}$ & $\begin{array}{l}5.64 \mathrm{E}-76 \\
2.96 \mathrm{E}-75 \\
4.39 \mathrm{E}-75\end{array}$ & $\begin{array}{l}264.2 \\
260.4 \\
261.9\end{array}$ & $\begin{array}{l}47.0 \\
51.2 \\
46.7\end{array}$ \\
\hline $\begin{array}{l}\text { comp46343 } \\
\text { (partial) }\end{array}$ & 1098 & $186-552$ & $\begin{array}{c}\text { EMP27581.1 } \\
\text { ADH93592.1 } \\
\text { AAG28398.1|AF192407_1 }\end{array}$ & $\begin{array}{c}\text { Chelonia mydas } \\
\text { Acipenser sinensis } \\
\text { Pimephales promelas }\end{array}$ & $\begin{array}{l}4.45 \mathrm{E}-28 \\
4.21 \mathrm{E}-19 \\
9.14 \mathrm{E}-16\end{array}$ & $\begin{array}{l}107.8 \\
95.10 \\
85.90\end{array}$ & $\begin{array}{l}42.4 \\
37.7 \\
37.4\end{array}$ \\
\hline comp38201 & 1485 & 219-993 & $\begin{array}{l}\text { AAB39079.1 } \\
\text { AAH61428.1 } \\
\text { AAV35105.1 }\end{array}$ & $\begin{array}{c}\text { Xenopus laevis } \\
\text { Xenopus (Silurana) tropicalis } \\
\text { Meleagris gallopavo }\end{array}$ & $\begin{array}{l}2.48 \mathrm{E}-120 \\
1.01 \mathrm{E}-117 \\
1.80 \mathrm{E}-115\end{array}$ & $\begin{array}{l}371.7 \\
365.5 \\
359.0\end{array}$ & $\begin{array}{l}50.3 \\
52.7 \\
51.9\end{array}$ \\
\hline \multicolumn{8}{|l|}{ ZPX } \\
\hline comp64828 & 3002 & $1506-2268$ & $\begin{array}{l}\text { AAl69766.1 } \\
\text { NP_988851.1 } \\
\text { ABQ9459.1 }\end{array}$ & $\begin{array}{c}\text { Xenopus laevis } \\
\text { Xenopus (Silurana) tropicalis } \\
\text { Numida meleagris }\end{array}$ & $\begin{array}{l}0 \\
0 \\
0\end{array}$ & $\begin{array}{l}843.2 \\
814.7 \\
703.4\end{array}$ & $\begin{array}{l}49.1 \\
47.1 \\
42.8\end{array}$ \\
\hline \multicolumn{8}{|l|}{ ZPD } \\
\hline comp68322 & 1528 & $339-1092$ & $\begin{array}{l}\text { NP_998741.2 } \\
\text { BAF56912.1 } \\
\text { AAI57425.1 }\end{array}$ & $\begin{array}{l}\text { Gallus gallus } \\
\text { Coturnix japonica } \\
\text { Xenopus laevis }\end{array}$ & $\begin{array}{l}2.11 \mathrm{E}-69 \\
5.01 \mathrm{E}-68 \\
1.09 \mathrm{E}-55\end{array}$ & $\begin{array}{l}238.8 \\
235.3 \\
201.1\end{array}$ & $\begin{array}{l}37.4 \\
37.1 \\
38.4\end{array}$ \\
\hline
\end{tabular}

were found as ZPC/ZP3 homologues, including a homologue of Xenopus laevis ZPC (Makabe-Kobayashi et al., 2003; accession: KM085177).

ZPC/ZP3 is a major component of the egg envelope participating in sperm binding in $X$. laevis (Vo and Hedrick, 2000; Kubo et al., 2002; Hedrick, 2008), although a homologue of $X$. laevis ZPC did not participate in the sperm binding to the egg envelope in $C$. pyrrhogaster(Makabe-Kobayashi et al., 2003). Thus, the molecular mechanism for sperm binding to the egg envelope differs between the species. In the fertilization process, binding to the egg envelope occurs with acrosome-intact spermatozoa in X. laevis (Ueda et al., 2002; Kubo et al., 2008) or with acrosome-reacted spermatozoa in C. pyrrhogaster (Nakai et al., 1999; Sasaki et al., 2002), as in mouse (Jin et al., 2011). The sperm binding in $C$. pyrrhogaster and mouse shows an additional similarity: sperm binding is modulated by oviduct-secreted substances and heparin (Nakai et al., 1999; Hiyoshi et al., 2007; Coy et al., 2008). From these facts, it was supposed that ZPA/ZP2 was a critical sperm receptor of the egg envelope in C. pyrrhogasteras in mammals (Bleil and Wassarman, 1988; Avella et al., 2014).

However, in the present study we found the unexpected expression of ZP proteins including six distinct molecules of ZP3/ZPC, a ZP4 and a ZP1 in the egg envelope of $C$. pyrrhogaster. In the NCBI GenBank, $X$. laevis and $X$. (S.) tropicalis possess one and two ZPC homologues, respectively. This indicated that the ZPC/ $Z P 3$ gene might be highly multiplicated, specifically in the $C$. pyrrhogastergenome. Furthermore, the egg envelope of $C$. pyrhogaster was suggested to possess a ZP4 and a ZP1 homologue, which are not identified in that of $X$. laevis. Those newly identified ZP proteins should be considered in order to understand the molecular mechanism underlying sperm binding to the egg envelope in $C$. pyrrhogaster.

\section{Voltage-dependent $\mathrm{Ca}^{2+}$ channel (VDCCs)}

Homologous base sequences to $\alpha 1 \mathrm{~B}, \mathrm{C}, \mathrm{D}, \mathrm{H}, \mathrm{L}$, and $\mathrm{S}$ subunits were found in the testis RNAseq data (Table 2). $\alpha 1 C, D$, $H$, L, and $S$ subunits were detected in both spermatogenic and nonspermatogenic testes by reverse transcription-polymerase chain reaction (Fig. 2) with stronger expression of $\alpha 1 \mathrm{C}, \mathrm{H}$, and $\mathrm{S}$ in spermatogenic testes. Elongation factor $(E F) 1$ gene expression was detected at similar levels in both testes, and a spermatidspecific gene, protamine 1 (Yoshinobu et al., 1997), was detected only in spermatogenic testes. These results suggest that the Ltype VDCCs, CaV1.1 and 1.2, and a T-type VDCC, CaV3.2. were expressed in spermatozoa.

Calcium ion is a significant intracellular mediator for multiple sperm functions, such as sperm acrosome reaction (Darszon et al., 2006; Florman et al., 2008), initiation/activation of sperm 
Fig. 2. Reverse transcription PCR of $\alpha 1$ subunits of VDCC genes annotated in the RNAseq data from testis. One- $\mu$ g of total RNA from spermatogenic (S) or non-spermatogenic (NS) testes was reverse transcribed and PCR was subsequently performed using specific primer set for $\alpha 1 \mathrm{~S}$ subunit (CaV1.1), $\alpha 1 \mathrm{C}$ subunit (CaV1.2), $\alpha 1 \mathrm{D}$ subunit (CaV1.3), $\alpha 1 \mathrm{H}$ subunit (CaV3.2) and $\alpha 1$ I subunit (CaV3.3) (See Table S1). As the controls, primer sets specific for protamine 1 and elongation factor (EF) 1 genes were used.

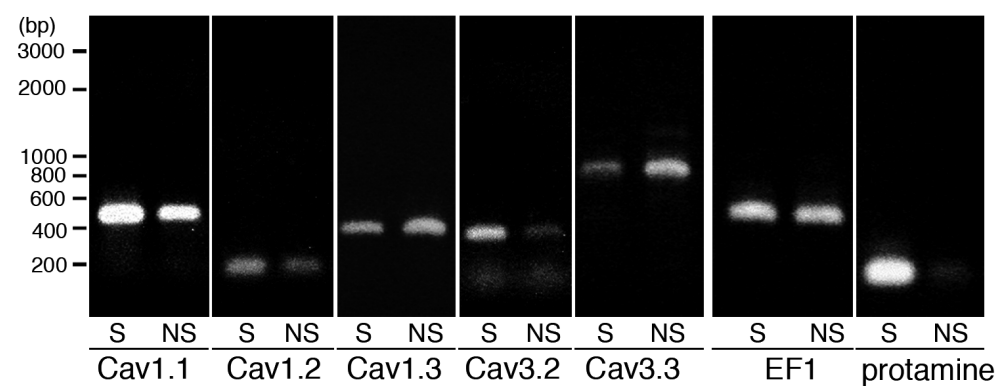

motility (Morisawa et al., 1999; Darszon et al., 2006; Kirichok and Lishko, 2011), and sperm binding to the egg envelope (Saito et al., 2012). Spermatozoa possess multiple types of cation channels in the plasma membrane and $\mathrm{Ca}^{2+}$ stores, which are critical for increasing cytoplasmic $\mathrm{Ca}^{2+}$ in every step of sperm-egg interaction (Darszon et al., 2006; Marquez et al., 2007). In the internal fertilization of $C$. pyrrhogaster, a unique mechanism for acrosome reaction-associated sperm motility initiation acts on the surface of the jelly layer (Fig. 1). When spermatozoa in the sperm reservoir of the female are inseminated onto the surface of the jelly layer, they undergo acrosome reaction in response to acrosome reactioninducing substances (ARIS) in the sheet structure covering the outer surface of the jelly layer (Watanabe et al., 2010). The sheet structure is digested possibly by acrosomal enzymes released by the acrosome reaction, which results in the exposure of granules containing sperm motility-initiating substance (SMIS) (Watanabe et al., 2010; Yokoe et al., 2014). A pharmacological study using T-type VDCC blockers, including mibefradil, and L-type VDCC blockers, including nitrendipine, suggests that CaV3.1 or 3.3 of the spermatozoa is involved in the induction of the acrosome reaction by $\mathrm{ARIS}$ and $\mathrm{CaV} 3.2$ in the initiation of SMIS-induced sperm motility (Takayama-Watanabe et al., 2015). In addition, a nitrendipine-sensitive $\mathrm{Ca}^{2+}$ channel and a mibefradil-sensitive $\mathrm{Ca}^{2+}$ channel predominantly mediate the increase of intracellular $\mathrm{Ca}^{2+}$ to enhance sperm motility in the anterior and posterior midpiece, respectively (Takahashi et al., 2013). The local enhancements are suggested to cause a specific state of motility crucial for spermatozoa to penetrate the jelly matrix.

The results of the present study suggest that $\mathrm{CaV} 3.2$ is actually present in spermatozoa and may involve in the initiation of sperm motility, and CaV1.1 and/or 1.2 can mediate the enhancement of sperm motility to penetrate the jelly layer. On the other hand, the expression in spermatozoa of CaV 3.1 or 3.3, each of which are thought to be involved in the induction of the acrosome reaction, was unclear (Fig. 2). This may indicate the involvement of the CatSper channel in the sperm function. Mibefradil is a major blocker of the CatSper channel in mammalian spermatozoa (Strünker et al., 2011; Lishko et al., 2011). Although we could not find base sequences annotated as CatSper in the RNAseq data, it may be difficult to identify homologues of the rapidly evolving CatSper by a BLAST search (Cai and Clapham, 2008). It is worth trying to identify the CatSper gene of $C$. pyrrhogaster using another method.

The presence of multiple VDCCs is a common feature in the spermatozoa of the animal species examined. In mammalian spermatozoa, seven types of VDCCs, including L-type, N/P/Qtype, and T-type, are expressed (Darszon et al., 2006). The role

TABLE 2

\section{CONTIG SEQUENCES HOMOLOGOUS TO $\alpha 1$ SUBUNITS OF VDCCs IN THE RNASEQ DATA FROM TESTIS}

\begin{tabular}{|c|c|c|c|c|c|c|}
\hline contigs & length (bp) & accession & species & E-value & bit score & identical (\%) \\
\hline \multicolumn{7}{|l|}{$\begin{array}{l}\text { testis } \\
\text { VDCC } \\
\text { a1 S (CaV1.1) }\end{array}$} \\
\hline comp387802 & 443 & $\begin{array}{l}\text { XP_002809678.1 } \\
\text { EMP32289.1 } \\
\text { XP_002941452.1 }\end{array}$ & $\begin{array}{l}\text { Pongo abelii } \\
\text { Chelonia mydas } \\
\text { Xenopus (Silurana) tropicalis }\end{array}$ & $\begin{array}{l}2.62 \mathrm{E}-82 \\
8.58 \mathrm{E}-81 \\
1.90 \mathrm{E}-80\end{array}$ & $\begin{array}{l}266.9 \\
268.1 \\
266.9\end{array}$ & $\begin{array}{l}95.4 \\
97.0 \\
95.4\end{array}$ \\
\hline \multicolumn{7}{|l|}{$\alpha 1 \mathrm{C}(\mathrm{CaV} 1.2)$} \\
\hline comp648010 & 320 & $\begin{array}{c}\text { BAD92253.1 } \\
\text { XP_003313479.1 }\end{array}$ & $\begin{array}{l}\text { Homo sapiens } \\
\text { Pan troglodytes }\end{array}$ & $\begin{array}{l}5.08 \mathrm{E}-24 \\
1.51 \mathrm{E}-23\end{array}$ & $\begin{array}{l}105.1 \\
104.8\end{array}$ & $\begin{array}{l}71.7 \\
71.7\end{array}$ \\
\hline \multicolumn{7}{|l|}{ a1 D (CaV1.3) } \\
\hline comp158103 & 761 & $\begin{array}{c}\text { NP_990365.1 } \\
\text { EMC88796.1 } \\
\text { NP_001072929.1 }\end{array}$ & $\begin{array}{l}\text { Gallus gallus } \\
\text { Columba livia } \\
\text { Xenopus (Silurana) tropicalis }\end{array}$ & $\begin{array}{l}4.95 \mathrm{E}-126 \\
1.43 \mathrm{E}-125 \\
2.75 \mathrm{E}-122\end{array}$ & $\begin{array}{l}404.8 \\
403.7 \\
374.4\end{array}$ & $\begin{array}{l}84.5 \\
84.5 \\
81.8\end{array}$ \\
\hline \multicolumn{7}{|l|}{ a1 B (CaV2.2) } \\
\hline comp161304 & 981 & $\begin{array}{c}\text { DAA24110.1 } \\
\text { EAW88415.1 } \\
\text { AAD51821.1|AF173018_1 }\end{array}$ & $\begin{array}{l}\text { Bos taurus } \\
\text { Homo sapiens } \\
\text { Gallus gallus }\end{array}$ & $\begin{array}{c}0 \\
3.77 \mathrm{E}-179 \\
1.74 \mathrm{E}-178\end{array}$ & $\begin{array}{l}543.5 \\
533.9 \\
556.2\end{array}$ & $\begin{array}{l}89.6 \\
88.0 \\
92.3\end{array}$ \\
\hline \multicolumn{7}{|l|}{ a1 H (CaV3.2) } \\
\hline comp55396 & 5503 & $\begin{array}{c}\text { XP_002932520.1 } \\
\text { XP_414830.3 } \\
\text { XP_002187949.2 }\end{array}$ & $\begin{array}{l}\text { Xenopus (Silurana) tropicalis } \\
\text { Gallus gallus } \\
\text { Taeniopygia guttata }\end{array}$ & $\begin{array}{l}0 \\
0 \\
0\end{array}$ & $\begin{array}{l}1508 \\
1359 \\
1321\end{array}$ & $\begin{array}{l}73.3 \\
66.9 \\
68.1\end{array}$ \\
\hline \multicolumn{7}{|l|}{ a1 I (CaV3.3) } \\
\hline comp42249 & 1288 & $\begin{array}{c}\text { XP_002933803.1 } \\
\text { XP_425474.2 } \\
\text { XP_003221064.1 }\end{array}$ & $\begin{array}{l}\text { Xenopus (Silurana) tropicalis } \\
\text { Gallus gallus } \\
\text { Anolis carolinensis }\end{array}$ & $\begin{array}{l}8.72 \mathrm{E}-70 \\
2.08 \mathrm{E}-64 \\
2.32 \mathrm{E}-54\end{array}$ & $\begin{array}{l}251.5 \\
235.7 \\
206.5\end{array}$ & $\begin{array}{l}60.2 \\
49.7 \\
52.1\end{array}$ \\
\hline
\end{tabular}


TABLE 3

\section{CONTIG SEQUENCES HOMOLOGOUS TO CRISPS IN THE RNASEQ DATA FROM UTERUS}

\begin{tabular}{lcl} 
contig & length (bp) & homologous protein \\
\hline comp48729 & 1396 & $\begin{array}{l}\text { cysteine-rich secretory protein 2 precursor [Mus musculus] } \\
\text { Serotriflin [Caprimulgus carolinensis] } \\
\text { cysteine-rich secretory protein 2 [Bos mutus] }\end{array}$ \\
comp47835 & $1182 \quad \begin{array}{l}\text { MGC108118 protein precursor [Xenopus (Silurana) tropicalis] } \\
\text { natrin-2 [Gallus gallus] } \\
\text { cysteine-rich seceretory protein Az-CRP [Azemiops feae] }\end{array}$ \\
\hline
\end{tabular}

of each VDCC appears to be redundant, because mice in which one VDCC gene is disrupted are sometimes fertile (Sakata et al., 2002; Chen et al., 2003; Stamboulian et al., 2004). Compared with mammalian spermatozoa, only 2 L-type and 1 T-type VDCC appeared to be expressed in those of $C$. pyrrhogaster (Fig. 2) and thus act with less redundancy. In internal fertilization, mammalian spermatozoa, unlike those of $C$. pyrrhogaster, make long trips through the oviduct. In that process, spermatozoa are deposited in the isthmus and capacitated with increasing intracellular $\mathrm{Ca}^{2+}$ (Kopf et al., 1999). The expression of redundant VDCCs in mammalian spermatozoa may correlate with the appropriate maintenance of intracellular $\mathrm{Ca}^{2+}$ in spermatozoa passing through the oviduct.

\section{Cysteine rich secretory proteins (CRISPs)}

CRISP proteins are reported to be expressed in the male reproductive tract of mammals and to modulate sperm maturation in the epididymis, as well as capacitation and fusion with the egg plasma membrane in the oviduct, at fertilization (Cohen et al., 2000; Roberts et al., 2003; Gibbs et al., 2006; Busso et al., 2007a; 2007b; Burnett et al., 2008a; Cohen et al., 2008). In amphibians, allurin, a member of the CRISP family proteins, is expressed in the oviduct (Al-Anzi and Chandler, 1998; Olson et al., 2001; Xiang et al., 2004). This protein is accumulated as a jelly component and diffuses into the medium to attract spermatozoa (Xiang et al., 2004). Allurin possesses a unique structure lacking an ion channel regulatory domain, which is conserved in the 3'-region of CRISP family proteins (Burnett et al., 2008a). The allurin gene is not functionally conserved in higher vertebrates, suggesting that allurin mediates a fertilization mechanism specific to Xenopus species. Allurin-mediated chemotaxis is not involved in the internal fertilization of $C$. pyrrhogaster, which lacks sperm attraction to eggs in the fertilization process, although CRISP family proteins including allurin may contribute to some other events in the egg jelly of urodele species. Thus, we surveyed the RNAseq data from the uterus of the oviduct, where components of the outermost region of the jelly layer are secreted at ovulation (Okimura et al., 2001), and found two base sequences homologous to CRISP family proteins (Table 3). Comp48729 was annotated as CRISP 2, whose expression in the oviduct had not been reported until now. The other contig, comp47835, here called CRISP-like protein, displays high homology to several proteins belonging to the CRISP family. It contains both a pathogenesis-related domain and an ion channel regulatory domain. Reverse-transcription PCR revealed that mRNA having both contig sequences was expressed in the uterus and pars convoluta (Fig. 3). Allurin is reported to be the only CRISP family protein expressed in the $X$. (S.) tropicalis oviducts (Burnett et al., 2008b), and no CRISP family protein apparently expresses in mammalian oviducts (Burnett et al., 2008a). Thus, it is remarkable that the putative CRISP 2 and CRISP-like protein were expressed in the $C$. pyrrhogaster oviducts.

\begin{tabular}{cccc} 
accession & E-value & bit score & identical (\%) \\
\hline NM_009420.2/NP_033446.1 & $8.00 \mathrm{E}-57$ & 191 & 48.0 \\
KFZ46955.1 & $9.00 \mathrm{E}-57$ & 188 & 54.0 \\
ELR49508.1 & $1.00 \mathrm{E}-55$ & 188 & 49.0 \\
NM_001030355 & $1.27 \mathrm{E}-69$ & 232.6 & 50.0 \\
XP_420051.3 & $2.15 \mathrm{E}-66$ & 221.9 & 50.5 \\
ACE73558.1 & $3.19 \mathrm{E}-66$ & 221.5 & 47.0 \\
\hline
\end{tabular}

The expression of comp48729 was increased in the uterus but reduced in the pars convolute, whereas the expression of comp 47835 was decreased in both the uterus and the pars convoluta of HCG-injected females (Fig. 3). In the controls, the expression of EF1 was ubiquitous, whereas that of $\alpha$-type estrogen receptor was reduced in the oviduct following HCG injection. The reduced expression of the estradiol receptor by HCG treatment has been reported in mammalian tissue (Chiang et al., 2000), suggesting that the RNA obtained from the oviduct of HCG-treated females actually contained mRNA whose transcription was affected by the HCG signal. Because HCG induced the secretion of jelly components as well as ovulation, the upregulation of CRISP 2 gene expression by HCG indicates that CRISP 2 protein may be abundantly present in the outer surface of the egg jelly. This protein may modulate the acrosome reaction-associated motility initiation on the surface of the egg jelly. Alternatively, it may be responsible for antibacterial effects after females spawned eggs into fresh water, as the CRISP family proteins function as reptile venom (Burnett et al., 2008a). Further study is needed to evaluate the significance of the newly found CRISP family protein in the internal fertilization and embryonic development of $C$. pyrrhogaster.

RNAseq data from ovary, testis, and oviduct samples demonstrated its usefulness in providing gene lists for fertilization research in C. pyrrhogaster. In the present study, we first found that 1) egg envelopes were composed of a unique combination of ZP proteins, including ZP1, ZP4, and six isoforms of ZPC, which are thought to be responsible for the $C$. pyrrhogaster-specific mechanism underlying sperm binding to the egg envelope; 2) two L-type VDCCs, CaV1.1 and 1.2, and a T-type VDCC, CaV3.2, which are proposed to act in the initiation and enhancement of sperm motility (Takahashi et al.,

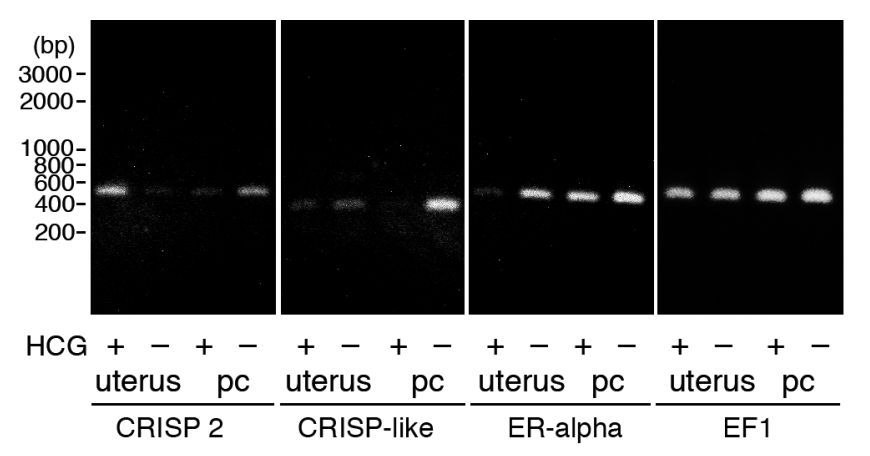

Fig. 3. Reverse transcription PCR of CRISP genes annotated in the RNAseq data from uterus. One- $\mu g$ of total RNA from uterus or pars convolute $(p c)$ of oviduct dissected from ovulation-induced (+) or notinduced (-) females was reverse transcribed and PCR was subsequently performed using specific primer sets for CRISP 2 and CRISP-like protein. Primer sets of estrogen receptor (ER)- $\alpha$ and elongation factor (EF) 1 genes were used as the controls. 
2013; Takayama-Watanabe et al., 2015), were actually present in spermatozoa; and 3) CRISP 2 might participate in the acrosome reaction-associated initiation of sperm motility critical for the success of internal fertilization.

Construction of omics data has already been reported in the newt Nothophtalmus viridescens, and the presence of many newtspecific transcripts as well as genes conserved in vertebrates has been revealed (Looso et al., 2013). Furthermore, advances in gene technology allowed DNA targeting in newts using TAL effector-like nuclease (Hayashi et al., 2014; Flowers et al., 2014). These technologies will contribute to the further elucidation of the molecular mechanisms underlying fertilization events in nonmodel amphibian species.

\section{Materials and Methods}

\section{RNAseq data}

De novo assembled RNAseq data that were constructed using Trinity (http://trinityrnaseq.sourceforge.net) and annotated using NCBI GenBank were provided by Dr. Chiba, C. of Tsukuba University and Dr. Toyama, F. of Utsunomiya University (http://antler.is.utsunomiya-u.ac.jp/imori/). Messenger RNA for the data construction was from the spermatogenic testes, ovaries containing all stages of oocytes, and the most posterior portion of the oviduct, the uterus. The uterus is the portion where most components of the outer surface of jelly layer are secreted (Okimura et al., 2001). For the RNA preparation from the uterus, females in which secretion of jelly components was stimulated by human chorionic gonadotoropin (HCG) was used.

\section{Animals}

Sexually mature newts were captured in Yamagata Prefecture in late autumn. Spermatogenic and non-spermatogenic testes were dissected from males immediately and after a 1-year hibernation at $10^{\circ} \mathrm{C}$ in labo. It has been reported that in $C$. pyrrhogaster, incubation of males at low temperature results in cessation of meiosis and spermiogenesis (Yazawa et al., 2003). Oviducts were obtained from females in which ovulation was induced by two injections of 200 IU HCG (ASKA Pharmaceutical Co., Tokyo Japan) at a 24-h interval. The uterus and second posterior portion, the pars convolute, where components of the inner jelly layer are secreted (Okimura et al., 2001) were dissected. Total RNA was prepared from the testis, uterus, and pars convolute using Trizo ${ }^{\circledR}$ reagent (Invitrogen).

\section{Reverse-transcription PCR}

One- $\mu \mathrm{g}$ of total RNA was reverse transcribed using SMARTScript ${ }^{\mathrm{TM}}$ reverse transcriptase (Clontec), and subsequent PCR was performed using $2 \mu \mathrm{l}$ and $4 \mu \mathrm{l}$ of the reacted solution from testis and oviduct (uterus or pars convolute) samples, respectively. The reaction was performed with 30 or 35 cycles of denaturing at $95^{\circ} \mathrm{C}$ for $30 \mathrm{sec}$, annealing at 58 or $60^{\circ} \mathrm{C}$ for $30 \mathrm{sec}$, and extension at $72^{\circ} \mathrm{C}$ for $1 \mathrm{~min}$. Gene-specific primers were designed from the limited region of the base sequence of RNAseq data that have high homology to the examined gene of the other animals (Table S1). The amplified DNA was electrophoresed in $1 \%$ agarose gels and visualized using $10 \mu \mathrm{g} / \mathrm{ml}$ ethidium bromide.

\section{Acknowledgements}

We express special thanks to all members of the Japan newt research community for valuable comments and discussion. This work was supported by grants from the Ministry of Education, Culture, Sports, Science and Technology (221S0002) and the Japan Society for the Promotion of Science (24570246, 24240062).

\section{References}

AL-ANZI B, CHANDLER DE (1998). A sperm chemoattractant is released from Xenopus egg jelly during spawning. Dev Biol 198: 366-375.

AVELLA MA, BAIBAKOV B, DEAN J. (2014). A single domain of the ZP2 zona pellucida protein mediates gamete recognition in mice and humans. J. Cell Biol. 205: 801-809.

BLEILJD, GREVE JM, WASSARMAN PM (1988). Identification of a secondary sperm receptor in the mouse egg zona pellucida: Role in maintenance of binding of acrosome-reacted sperm to eggs. Dev Biol 28: 376-385.

BURNETT LA, XIANG X, BIEBER AL, CHANDLER DE (2008a). Crisp proteins and sperm chemotaxis: discovery in amphibians and explorations in mammals. Int $J$ Dev Biol 52:489-501.

BURNETT LA, BOYLES S, SPENCER C, BIEBER AL, CHANDLER DE (2008b). Xenopus tropicalisallurin: expression, characterization and sperm chemoattractant activity. Dev. Biol. 316: 408-416.

BUSSO D, COHEN DJ, MALDERA JA, DEMATTEIS A, CUASNICU PS (2007a). A novel function for CRISP1 in rodent fertilization: Involvement in sperm-zona pellucida interaction. Biol Reprod 77:848-854.

BUSSO D, GOLDWEIC NM, HAYASHI M, KASAHARA M, CUASNICU PS (2007b). Evidence for the involvement of testicular protein CRISP2 in mouse sperm-egg fusion. Biol Reprod 76:701-708.

CAI X, CLAPHAM DE (2008). Evolutionary genomics reveals lineage-specific gene loss and rapid evolution of a sperm-specific ion channel complex: CatSpers and CatSper $\beta$. PLoS One 3: e3569.

CHEN CC, LAMPING KG, NUNO DW, BARRESI R, PROUTY SJ, LAVOIE JL, CRIBBS LL, ENGLAND SK, SIGMUND CD, WEISS RM, WILLIAMSON RA, HILL JA, CAMPBELL KP (2003). Abnormal coronary function in mice deficient in $\alpha 1 \mathrm{H}$ T-type $\mathrm{Ca}^{2+}$ channels. Science 302: 1416-1418.

CHERR GN, MORISAWA M, VINES CA, YOSHIDA K, SMITH EH, MATSUBARA T, PILLAI MC, GRIFFIN FJ, YANAGIMACHI R (2008). Two egg-derived molecules in sperm motility initiation and fertilization in the Pacific herring (Clupea pallasi). Int J Dev Biol 52: 743-572.

COHEN DJ, ROCHWERGER L, ELLERMAN DA, MORGENFELD M, BUSSO D, CUASNICU PS (2000). Relationship between the association of rat epididymal protein DE with spermatozoa and the behavior and function of the protein. Mol Reprod Dev 56: 180-188.

COHEN DJ, BUSSO D, ROS VD, ELLERMAN DA, MALDERA JA, GOLDWEIC N CUASNICU PS (2008). Participation of cysteine-rich secretory proteins (CRISP) in mammalian sperm-egg interaction. Int J Dev Biol 52: 737-742.

COY P, CÁNOS S, MONDÉJAR I, SAAVEDRA MD, ROMAR R, GRULLÓN L, MATÁS C, AVILÉS M (2008). Oviduct-specific glycoprotein and heparin modulate sperm-zona pellucida interaction during fertilization and contribute to the control of polyspermy. Proc. Natl. Acad. Sci. USA 105: 15809-15814.

DARSZON A, ACEVEDO JJ, GALINDO BE, HERNÁNDEZ-GONZÁLEZ EO, NISHIGAKI T, TREVIÑO CL, WOOD C, BELTRÁN C (2006). Sperm channel diversity and functional multiplicity. Reproduction 131: 977-988.

DUELLMAN WE, TRUEB L (Eds) (1994). Biology of Amphibians. Johns Hopkins University Press, Baltimore, MD.

FLORMAN HM, JUNGNICKEL MK, SUTTON KA (2008). Regulating the acrosome reaction. Int J Dev Biol 52: 503-510.

FLOWERS GP, TIMBERLAKE AT, MCLEAN KC, MONAGHAN JR, CREWS CM (2014). Highly efficient targeted mutagenesis in axolotl using Cas9 RNA-guided nuclease. Development 141: 2165-2171.

FROMAN DP, FELTMANN AJ (2005). Fowl (Gallus domesticus) sperm motility depends upon mitochondrial calcium cycling driven by extracellular sodium. Biol Reprod 72: 97-101.

GIBBS GM, SCANLON MJ, SWARBRICK J, CURTIS S, GALLANT E, DULHUNTY AF, O'BRYAN MK (2006). The Cysteine-rich Secretory Protein Domain of Tpx-1 Is Related to lon Channel Toxins and Regulates Ryanodine Receptor $\mathrm{Ca}^{2+}$ Signaling. J Biol Chem 281: 4156-4163.

GOUDET G, MUGNIER S, CALLEBAUT I, MONGETP (2008). Phylogenetic analysis and identification of pseudogenes reveal a progressive loss of zona pellucida genes during evolution of vertebrates. Biol Reprod 78: 796-806. 
HAYASHI T, SAKAMOTO K, SAKUMA T, YOKOTANI N, INOUE T, KAWAGUCHI E, AGATA K, YAMAMOTO T, TAKEUCHI T (2014). Transcription activator-like effector nucleases efficiently disrupt the target gene in lberian ribbed newts (Pleurodeles walt), an experimental model animal for regeneration. Dev. Growth Differ 56: 115-121.

HEDRICK JL (2008). Anuran and pig egg zona pellucida glycoproteins in fertilization and early development. Int J Dev Biol 52: 683-701.

HIYOSHI W, SASAKI T, TAKAYAMA-WATANABE E, TAKAI H, WATANABE A, ONITAKE K (2007). Egg jelly of the newt, Cynops pyrrhogaster contains a factor essential for sperm binding to the vitelline envelope. J Exp Zool A 307: 301-311.

INODA T, MORISAWAM (1987). Effect of osmolality on the initiation of sperm motility in Xenopus laevis. Comp Biochem Physiol 88A: 539-542.

JIN M, FUJIWARA E, KAKIUCHI Y, OKABE M, SATOUH Y, BABA SA, CHIBA K, HIROHASHI N (2011). Most fertilizing mouse spermatozoa begin their acrosome reaction before contact with the zona pellucida during in vitro fertilization. Proc. Natl. Acad. Sci. USA 108: 4892-4896.

KILLICK R, LEGAN PK, MALENCZAK C, RICHARDSON GP (1995). Molecular cloning of chick beta-tectorin, an extracellular matrix molecule of the inner ear. J Cell Biol 129: 535-547.

KIRICHOK Y, LISHKO PV (2011). Rediscovering sperm ion channels with the patchclamp technique. Mol Hum Reprod 17: 478-499.

KOPF GS, NING XP, VISCONTIPE, PURDON M, GALANTINO-HOMERH, FORNÉS M (1999). Signaling mechanisms controlling mammalian sperm fertilization competence and activation. In The male Gamete: from basic science to clinical applications (Ed C Gagnon). Cache river press, Vienna, IL pp. 105-118.

KUBO H, KOTANI M, SUZUKI H, YOSHIZAKI N (2002). Immunohistochemical localisation of gp69/64 molecules in Xenopus egg envelopes in relation to their sperm binding activity. Zygote 10: 131-140.

KUBO H, KOTANI M, YAMAMOTO Y, HAZATO T (2008). Involvement of sperm proteases in the binding of sperm to the vitelline envelope in Xenopus laevis. Zool Sci 25: 80-87.

LISHKOPV, BOTCHKINAIL, KIRICHOKY (2011). Progesterone activates the principal $\mathrm{Ca}^{2+}$ channel of human sperm. Nature 471: 387-391.

LOOSOM, PREUSSNERJ, SOUSOUNIS K, BRUCKSKOTTEN M, MICHELCS, LIGNELLI E, REINHARDT R, HÖFFNER S, KRÜGER M, TSONIS PA, BORCHARDT T, BRAUN T (2013). A de novo assembly of the newt transcriptome combined with proteomic validation identifies new protein families expressed during tissue regeneration. Genome Biol 14: R16.

MAKABE-KOBAYASHI Y, KUDAIRA E, WATANABE A, ONITAKE K (2003). CpZPC, a newt ZPC molecule, localizes to the inner surface of the egg envelope. Int $J$ Dev Biol 47: 51-58.

MARQUEZ B, IGNOTZ G, SUAREZ SS (2007). Contributions of extracellular and intracellular $\mathrm{Ca}^{2+}$ to regulation of sperm motility: Release of intracellular stores can hyperactivate CatSper1 and CatSper2 null sperm. Dev Biol 303: 214-221.

NAKAI S, WATANABEA, ONITAKE K (1999). Sperm surface heparin/heparan sulfate is responsible for sperm binding to the uterine envelope in the newt, Cynops pyrrhogaster. Dev Growth Differ 41: 101-107.

NAKAMURAK, ISLAM MR, TAKAYANAGI M, YASUMURO H, INAMI W, KUNAHONG A, CASCO-ROBLES RM, TOYAMA F, CHIBA C (2014). A transcriptome for the study of early processes of retinal regeneration in adult newt, Cynops pyrrhogaster. PLOS One 9: e109831.

OKIMURA M, WATANABE A, ONITAKE K (2001). Organization of carbohydrate components in the egg-jelly layers of the newt, Cynops pyrrhogaster. Zool Sci 18: 909-918

OLSON J, XIANG X, ZIEGERT T, KITTLESON A, RAWLS A, BIEBERA, CHANDLER DE (2001). Allurin, a $21 \mathrm{kD}$ sperm chemoattractant from Xenopus egg jelly, is homologous to mammalian sperm-binding proteins. Proc. Natl. Acad. Sci. USA 98: 11205-11210.

PODLAHA O, ZHANG J (2003). Positive selection on protein- length in the evolution of a primate sperm ion channel. Proc. Natl. Acad. Sci. USA 100: 12241-12246.

REN D, NAVARRO B, PEREZ G, JACKSON AC, HSU S, SHI Q, TILLY JL, CLAPHAM DE (2001). A sperm ion channel required for sperm motility and male fertility. Nature 413: 603-609.
ROBERTS KP, WAMSTAD, JA, ENSRUD, KM, HAMILTON, DW (2003). Inhibition of capacitation-associated tyrosine phosphorylation signaling in rat sperm by epididymal protein crisp-1. Biol Reprod 69: 572-581.

SAITO T, SHIBA K, INABA K, YAMADA L, SAWADA H (2012). Self-incompatibility response induced by calcium increase in sperm of the ascidian Ciona intestinalis Proc. Natl. Acad. Sci. USA 109: 4158-4162.

SAKATA Y, SAEGUSA H, ZONG S, OSANAI M, MURAKOSHI T, SHIMIZU Y, NODA T, ASO T, TANABE T (2002). Ca(v)2.3 ( $\alpha 1 \mathrm{E}) \mathrm{Ca}^{2+}$ channel participates in the control of sperm function. FEBS Lett 516: 229-233.

STAMBOULIAN S, KIM D, SHIN HS, RONJAT M, DE WAARD M, ARNOULT C (2004). Biophysical and pharmacological characterization of spermatogenic Ttype calcium current in mice lacking the CaV3.1 ( $\alpha 1 \mathrm{G})$ calcium channel: CaV3.2 $(\alpha 1 \mathrm{H})$ is the main functional calcium channel in wild-type spermatogenic cells. $J$ Cell Physiol 200: 116-124.

STRÜNKER T, GOODWIN N, BRENKER C, KASHIKAR ND, WEYAND I, SEIFERTR, KAUPP UB (2011). The CatSper channel mediates progesterone-induced $\mathrm{Ca}^{2+}$ influx in human sperm. Nature 471: 382-386.

TAKAHASHI S, NAKAZAWA H, WATANABE A, ONITAKE K (2006). The outermost layer of egg-jelly is crucial to successful fertilization in the newt, Cynops pyrrhogaster. J Exp Zool 305A: 1010-1017.

TAKAHASHI T, KUTSUZAWA M, SHIBA K, TAKAYAMA- WATANABE E, INABA K, WATANABE A (2013). Distinct $\mathrm{Ca}^{2+}$ channels maintain a high motility state of the sperm that may be needed for penetration of egg jelly of the newt, Cynops pyrrhogaster. Dev Growth Differ 55: 657-667.

TAKAI H, MORISAWA M (1995). Change in intracellular $\mathrm{K}^{+}$concentration caused by external osmolality change regulates sperm motility of marine and freshwater teleosts. J Cell Sci 108: 1175-1181.

TAKAYAMA-WATANABE E, OCHIAI H, TANINO S, WATANABEA(2015). Contribution of different $\mathrm{Ca}^{2+}$ channels to the acrosome reaction-mediated initiation of sperm motility in the newt Cynops pyrrhogaster. Zygote 23: 342-351.

TIAN J, GONG H, LENNARZ WJ (1999). Xenopus laevis sperm receptor gp69/64 glycoprotein is a homolog of the mammalian sperm receptor ZP2. Proc. Natl. Acad. Sci. USA 96: 829-834.

UEDA Y, YSHIZAKI N, IWAO Y (2002). Acrosome reaction in sperm of the frog, Xenopus laevis: Its detection and induction by oviductal pars recta secretion. Dev Biol 243: 55-64.

VINES CA, YOSHIDA K, GRIFFIN FJ, PILLAI MC, MORISAWA M, YANAGIMACHI R, CHERR GN (2002). Motility initiation in herring sperm is regulated by reverse sodium-calcium exchange. Proc. Natl. Acad. Sci. USA 99: 2026-2031.

VO LH, HEDRICK JL (2000). Independent and hetero-oligomeric-dependent sperm binding to egg envelope glycoprotein ZPC in Xenopus laevis. Biol Reprod 62 766-774.

WATANABE T, KUBO H, TAKESHIMA S, NAKAGAWA M, OHTA M, KAMIMURA S, TAKAYAMA-WATANABE E, WATANABE A, ONITAKE K (2010). Identification of the sperm motility- initiating substance in the newt, Cynops pyrrhogaster, and its possible relationship with the acrosome reaction during internal fertilization. Int J Dev Biol 54: 591-597.

XIANG X, BURNETT LA, RAWLS A, BIEBERAL, CHANDLER DE (2004). The sperm chemoattractant "allurin" is expressed and secreted from the Xenopus oviduct in a hormone regulated manner. Dev Biol 275: 343-355.

YANAGIMACHIR (1994). Mammalian fertilization. In The Physiology of Reproduction, 2nd edn (Eds E Knobil, J. D. Neill). Raven Press, New York, NY, pp. 189-317.

YAZAWAT, NAKAYAMAY, FUJIMOTOK, MATSUDAY, ABE K, KITANOT, ABÉ S-I, YAMAMOTO T (2003). Abnormal spermatogenesis at low temperatures in the Japanese red-bellied newt, Cynops pyrrhogaster: Possible biological significance of the cessation of spermatocytogenesis. Mol Reprod Dev 66: 60-66.

YOKOE M, SANO M, SHIBATA H, SHIBATAD, TAKAYAMA-WATANABE E, INABAK WATANABE A. (2014). Sperm proteases that may be involved in the initiation of sperm motility in the newt, Cynops pyrrhogaster. Int J Mol Sci 15: 15210-15224.

YOSHINOBU K, KONDO T, TAKAI M, KATAGIRIK, TOU T, ABE S-I, TAKAMUNE K (1997). Primary structures of sperm-specific basic nuclear proteins and gene expression in Japanese newt, Cynops pyrrhogaster. Mol Reprod Dev 46:243-251. 
Further Related Reading, published previously in the Int. J. Dev. Biol.

Identification of the sperm motility-initiating substance in the newt, Cynops pyrrhogaster, and its possible relation with the acrosome reaction during internal fertilization Toshihiko Watanabe, Hideo Kubo, Shinya Takeshima, Mami Nakagawa, Manami Ohta, Saori Kamimura, Eriko Takayama-Watanabe, Akihiko Watanabe,, and Kazuo Onitake Int. J. Dev. Biol. (2010) 54: 591-597

CpZPC, a newt ZPC molecule, localizes to the inner surface of the egg envelope Youko Makabe-Kobayashi, Etsuko Kudaira, Akihiko Watanabe and Kazuo Onitake Int. J. Dev. Biol. (2003) 47: 51-58

Crisp proteins and sperm chemotaxis: discovery in amphibians and explorations in mammals.

Burnett LA, Xiang X, Bieber AL, Chandler DE.

Int J Dev Biol. (2008) 52: 489-501.

Anuran and pig egg zona pellucida glycoproteins in fertilization and early development. Hedrick JL.

Int J Dev Biol. (2008) 52: 683-701.

5 yr ISI Impact Factor $(2013)=2.879$
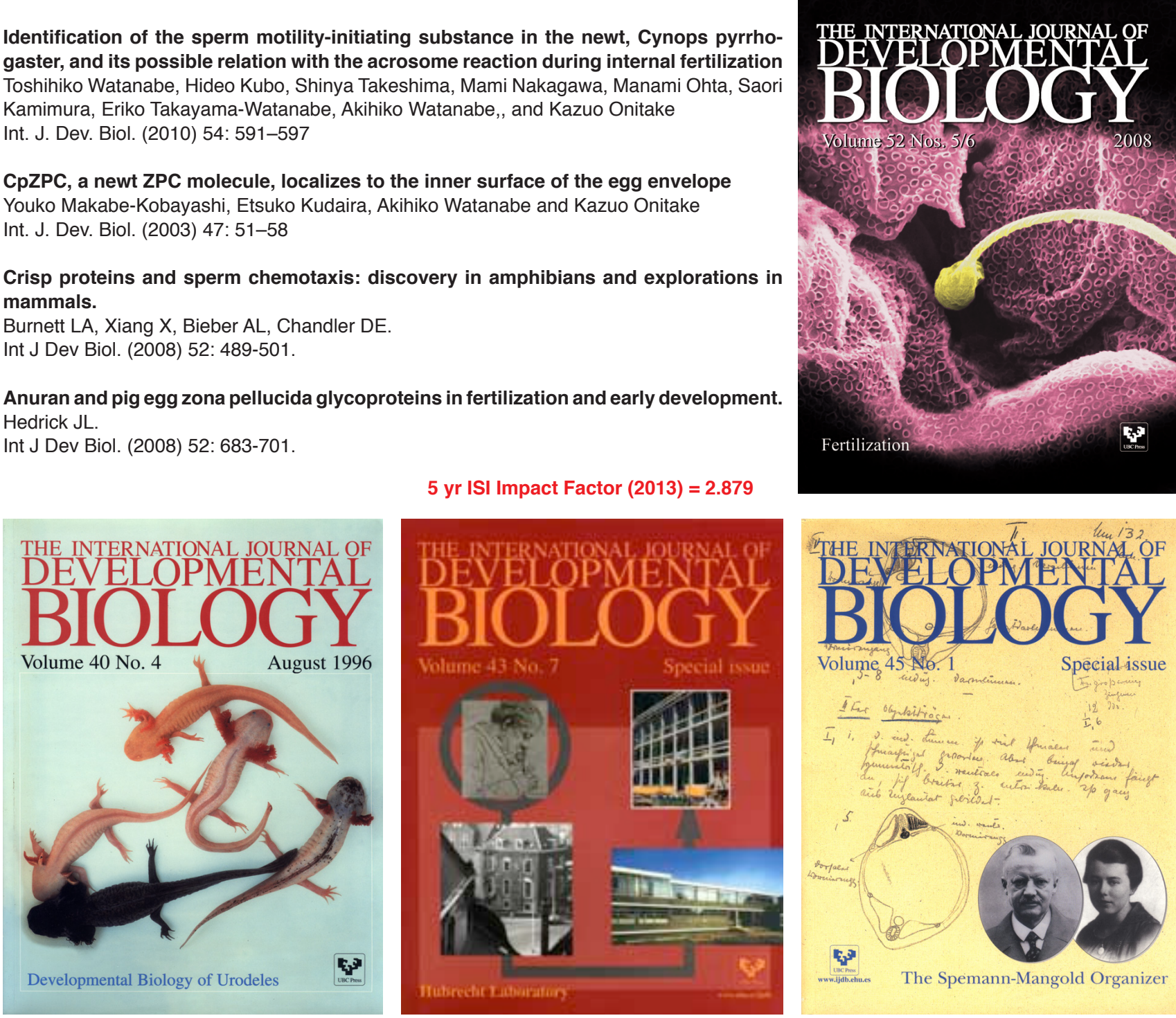

Volume 45 NO. 1

Special issue

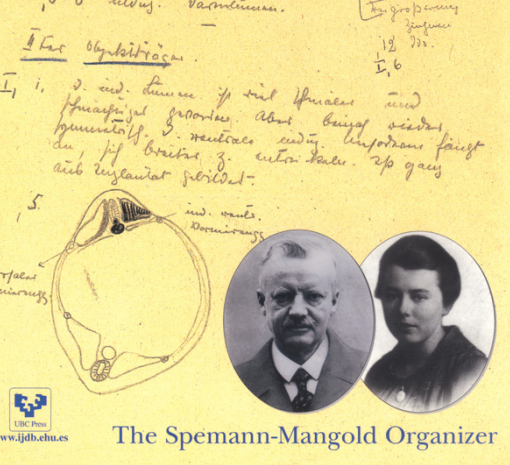

